\title{
SCREENING OF CHRONIC DISEASES AND CHRONIC DISEASE RISK FACTORS IN TWO RURAL COMMUNITIES IN KOSOVO
}

\author{
Gordana Šubarić Gorgieva ${ }^{1}$, Zvonko Stašević2 ${ }^{\text {, Suzana Vasić }}{ }^{1}$, Slavica Ristić ${ }^{1}$, Višnja Ležaićc ${ }^{3}$, \\ Ljubica Djukanović ${ }^{3}$ \\ 1Laplje Selo Hospital, Internal Clinic, Priština, Serbia \\ ${ }^{2}$ Health House Donja Gušterica, Liplian, Serbia \\ ${ }^{3} S$ chool of Medicine University of Belgrade, Belgrade, Serbia
}

\section{SUMMARY}

Background: A cross-sectional study was carried out in Velika Hoča and Orahovac, two rural communities in Kosovo and Metohia, with the aim of assessing the prevalence of chronic diseases and associated risk factors.

Methods: The study involved 423 (180 male) adult inhabitants aged $51 \pm 16$ years and included an interview, medical documentation, physical, ultrasound, laboratory examinations and ECG.

Results: Hyperlipidemia was the most frequent (70\%) risk factor followed by alcohol consumption (47\%), hypertension (42\%), smoking (36\%) and obesity (32\%). Ischemic heart disease was diagnosed in 25 patients, hypertensive cardiomyopathy in 17, other cardiomyopathies in 5 and arrhythmia in 20 patients. Nine persons had chronic obstructive pulmonary disease. Previously diagnosed liver cirrhosis occurred in 5 and chronic hepatitis in 8 subjects, while liver steatosis with elevated serum transaminases (22 persons), elevated transaminases with normal ultrasound (20 persons), tumor or suspected tumor (7 persons) were detected in the survey. Gastrointestinal symptoms were the most prevalent but peptic ulcer and gastritis had been previously diagnosed in 64 and 47 patients. Kidney and urinary tract diseases were known for 52 patients (12 with chronic renal failure and 4 on hemodialysis) and 46 more were detected in the study. Among them in 22 patients with markers of kidney disease and unclear diagnosis 12 had a positive family history, 8 low-grade proteinuria, 14 tubular dysfunctions and 7 eGFR (estimated glomerular filtration rate) below $60 \mathrm{~m} / \mathrm{min} / 1.73 \mathrm{~m}^{2}$.

Conclusion: In the Serbian enclave of Velika Hoča and Orahovac the prevalence of cardiovascular diseases was similar to that of gastrointestinal, liver and kidney diseases. This differs from other parts of Serbia where cardiovascular disorders are the leading cause of disease burden.

Key words: chronic disease prevalence, rural community, Kosovo and Metohia

Address for correspondence: L. Djukanović, Pere Velimirovića 54/15, 11000 Beograd, Serbia. E-mail: nefro@ eunet.rs

\section{INTRODUCTION}

Chronic diseases are the most frequent cause of death all over the world. The global prevalence of all the leading chronic diseases (cardiovascular, cancer, chronic lung diseases, diabetes mellitus) is increasing, with the majority occurring in developing countries (1). Although chronic kidney disease is not among the first ten conditions in terms of disability and mortality, it is becoming a global public health problem due to the great increase of patients on renal replacement therapy (2). Chronic diseases share key risk factors and therefore preventive measures directed to all these risk factors as well as early detection and prevention of chronic diseases are measures that could diminish their increasing prevalence $(1,3)$.

The whole population of Serbia experienced many social and economic threats during 1990s but since then life under severe conditions has continued in Kosovo and Metohia. Meanwhile, it was unfeasible to devote adequate attention to the disease prevention. Nevertheless, during 2003, we have carried out a screening survey in the Balkan nephropathy focus of Vitina, where in spite of the dramatic demographic changes of the Serb population during the period 1999-2000 high prevalence of kidney failure was found (4). In addition, physicians from the local primary care units in Velika Hoča and Orahovac have reported an increasing prevalence of patients suffering from chronic kidney diseases $(5,6)$. In order to confirm these data a cross sectional study was undertaken in Velika Hoča and Orahovac, two rural communities in a Serbian enclave situated in southwestern Kosovo and Metohia. Our team consisting of three doctors (two nephrologists, one cardiologist), two nurses, one laboratory technician and one driver, spent two months (July and August 2006), working in the health dispensary in Velika Hoča. The aim of the study was to assess the prevalence of risk factors for chronic diseases and to evaluate chronic disease burden with special attention to chronic kidney and urinary tract diseases in this population.

\section{PATIENTS AND METHODS}

The cross-sectional study involved all inhabitants above 18 years of age from Velika Hoča and Orahovac. According to available data 545 people remained in Orahovac after 1999 (around 
440 adults) and 700 (around 550 adults) in Velika Hoča $(5,6)$. Five hundred inhabitants responded to the invitation but only 423 were completely examined. There were 180 males and 243 females aged $51 \pm 16$ years. Informed consent was obtained from all patients and the Ethics Committee of the Medical Faculty, University of Belgrade approved the study.

The survey started with an interview in which the participants answered a detailed questionnaire on demographic issues, personal medical and family history including data on risk factors for chronic diseases and previously diagnosed diseases. Smoking status was categorized into never smoker and smoker who had smoked at least 100 cigarettes in his life. Alcohol intake was dichotomized on the basis of intake frequency, at least weekly (drinker) against rarely or never (nondrinker).

After the interview all persons were subjected to detailed physical examinations including measurement of body weight, height and blood pressure in addition to ECG and abdominal ultrasound. Arterial hypertension was diagnosed when systolic blood pressure was $\geq 140 \mathrm{mmHg}$ and/or diastolic pressure was $\geq 90 \mathrm{mmHg}$ or if antihypertensive treatment was prescribed. A history of cardiovascular disease was defined as the presence or absence of physician-diagnosed cardiomyopathy, an episode of myocardial infarction, angina and stroke.

At the time of the cross-sectional study the hematocrit was measured (Microhaematocrit Electro Mag.) and proteinuria and hemoglobinuria were estimated using visually read dipsticks (Chemstrip, 10 with SG; Roche). Fasting venous blood samples were collected from all participants to measure serum glucose, urea, creatinine, total protein, albumin, total cholesterol, HDL-cholesterol, LDL-cholesterol, triglycerides, ALT, AST, $\gamma$-GT, alkaline phosphatase, $\alpha$-amylase. All serum biochemical tests were carried out at the laboratory of the Laplje Selo Regional Hospital. In all persons with elevated serum aminotransferase levels, HBs antigen (commercial assay for HBV serologic testing, Abbott Laboratories, Chicago, Illinois, USA) and anti-HCV (third-generation commercial enzyme-linked immunosorbent assays ELISA 3 and RIBA 3; Ortho Diagnostics, Raritan, New Jersey, USA) were checked.

Persons were defined as having diabetes if fasting serum glucose was higher than $7 \mathrm{mmol} / \mathrm{l}$, or if they had a history of diabetes diagnosed by a physician and were being treated with insulin, oral hypoglycemic agents, or diet. Hyperlipidemia was defined by any one of the following: total cholesterol $\geq 5.2 \mathrm{mmol} / \mathrm{l}$, triglyceride $\geq 1.7 \mathrm{mmol} / \mathrm{l}$, high-density cholesterol $<1.0 \mathrm{mmol} / \mathrm{l}$, low-density cholesterol $\geq 3.4 \mathrm{mmol} / \mathrm{l}$ or self-report of taking medication to decrease the blood lipid level.

The GFR was estimated using the original Modification of Diet in Renal Disease (MDRD) Study formula (7):

eGFR $\left(\mathrm{ml} / \mathrm{min} / 1.73 \mathrm{~m}^{2}\right)=186 \times(\mathrm{Scr})^{-1.154} \mathrm{x}(\text { Age })^{-0.203} \times(0.742$ if female)

Abdominal ultrasound imaging was performed in all individuals to evaluate the liver, gallbladder and kidneys using a Sonoline Adara, Siemens, ultrasound machine with sector probe of 3.5 $\mathrm{MHz}$.

Subjects with a history of cardiovascular disease and all those with hypertension underwent a physical examination by a cardiologist, who also analyzed their ECG and available medical documentation.

Persons with any detected disorder indicating kidney disease were invited to bring fresh morning urine samples that was cen- trifuged, urinary sediments were examined and supernatant was immediately frozen and stored at $-25^{\circ} \mathrm{C}$. In these urine samples protein (biuret method), creatinine (kinetic rate Jaffe method), $\alpha_{1}$-microglobulin (immunoturbidimetric assay, Turbitex $\alpha_{1}$-microglobulin; Roche/Hitachi 902; normal value $<1.3 \mathrm{mg} / \mathrm{mmol}$ creatinine), N-acetyl-ß-d-glucosaminidase (NAG; colorimetric assay with 3-cresol-sulfonphthalein, Roche; normal value $<3.0 \mathrm{U} / \mathrm{l}$ ), alkaline phosphatase (colorimetric method; normal value $<0.37 \mathrm{U} / \mathrm{mmol}$ creatinine) were determined at the Institute of Medical Biochemistry, Clinical Center Serbia, Belgrade.

Descriptive statistics were presented as mean values \pm standard deviation (SD) for the numeric variables, or as frequencies for categorical variables. Prevalence of diagnosed chronic diseases was calculated by dividing the number of persons with the disease by the total number of eligible inhabitants in Velika Hoča and Orahovac and expressed as a percentage.

\section{RESULTS}

In the present cross sectional study 423 adult inhabitants from Velika Hoča and Orahovac were completely examined. The results of laboratory analyses for all examined persons are presented in Table 1 . The most frequently detected abnormalities were lipid disorders, but hyperglycemia, increased serum ALT level and proteinuria were found at similar frequencies of $18-21 \%$.

Using the data obtained from the questionnaire, physical and laboratory examinations the frequency of risk factors for chronic diseases was calculated (Table 2). Hyperlipidemia was the most common risk factor and hypertension, obesity, smoking and alcohol consumption appeared with similar frequencies of about $40 \%$. These data indicated that these communities may be at the high risk not only of cardiovascular disorders but also of chronic kidney and liver diseases.

The results of ultrasound examination of the liver, gallbladder and kidney for all 423 persons are presented in Table 3 . The most frequent pathological liver ultrasound finding was hepatic steatosis. Focal liver lesions were found in 10 persons and seven of them with ultrasound finding of tumor were referred to the regional clinical center for further examination.

Reduced length of the right and left kidney was observed in 38 and 24 persons, respectively. Cysts were also a frequent finding in examined population (Table 3).

Using the data obtained by questionnaire, physical, laboratory and ultrasound examinations a diagnosis of disease could be established in some individuals but other cases with different pathological findings and unclear diagnosis were referred to the regional clinical center for further examination.

Cardiovascular diseases were common in the examined population. A total of 179 patients had hypertension (Table 2). According to the medical history and documentation, as well as physical examination and ECG, heart diseases were found in 67 persons (Table 4).

Chronic obstructive pulmonary disease was found in 9 persons who had already been treated for this condition by their family doctor.

Five subjects had previously diagnosed liver cirrhosis, 5 chronic viral hepatitis and 3 chronic hepatitis of unknown etiology 
Table 1. Results of laboratory analyses for 423 adult inhabitants from Velika Hoča and Orahovac presented as means \pm SD and frequency of pathological findings

\begin{tabular}{|c|c|c|c|}
\hline Parameter & Reference values & Mean \pm SD & Pathological finding (\%) \\
\hline Hematocrit & $\begin{array}{l}m: 40-54 \% \\
f: 37-47 \%\end{array}$ & $\begin{array}{l}43.4 \pm 4.6 \\
39.7 \pm 3.5\end{array}$ & $\begin{array}{l}5.9 \\
9.5\end{array}$ \\
\hline Glucose & $3.9-6.1 \mathrm{mmol} / \mathrm{l}$ & $5.5 \pm 2.4$ & 21 \\
\hline Albumin & $34-55 \mathrm{~g} / \mathrm{l}$ & $45.7 \pm 4.4$ & 0.2 \\
\hline Total cholesterol & $<5.2 \mathrm{mmol} / \mathrm{l}$ & $6.4 \pm 1.7$ & 74.5 \\
\hline HDL-cholesterol & $\geq 1.0 \mathrm{mmol} / \mathrm{l}$ & $1.4 \pm 0.8$ & 22.9 \\
\hline LDL-cholesterol & $<3.4 \mathrm{mmol} / \mathrm{l}$ & $4.0 \pm 1.0$ & 23.9 \\
\hline Triglycerides & $<1.7 \mathrm{mmol} / \mathrm{l}$ & $2.0 \pm 0.9$ & 50.6 \\
\hline ALT & $<37 \mathrm{U} / \mathrm{l}$ & $28 \pm 15$ & 17.7 \\
\hline AST & $<41 \mathrm{U} / \mathrm{l}$ & $30 \pm 9$ & 9.7 \\
\hline \multirow{2}{*}{$\gamma-G T$} & $m:<55 \mathrm{U} / \mathrm{l}$ & $41 \pm 22$ & 5.2 \\
\hline & f: $<38 \mathrm{U} / \mathrm{l}$ & $22 \pm 16$ & 6.6 \\
\hline Alkaline phosphatase & $64-306 \mathrm{U} / \mathrm{I}$ & $191 \pm 67$ & 6.1 \\
\hline$\alpha$-amylase & $<220 \mathrm{U} / \mathrm{I}$ & $140 \pm 65$ & 6.4 \\
\hline Urea & $2.5-7.5 \mathrm{mmol} / \mathrm{l}$ & $5.2 \pm 2.3$ & 8.0 \\
\hline \multirow{2}{*}{ Creatinine } & $\mathrm{m}: 74-124 \mu \mathrm{mol} / \mathrm{l}$ & $81 \pm 61$ & 1.7 \\
\hline & f: $53-106 \mu \mathrm{mol} / \mathrm{l}$ & $64 \pm 52$ & 0.9 \\
\hline eGFR (MDRD) & $>60 \mathrm{ml} / \mathrm{min} / 1.73 \mathrm{~m}^{2}$ & $103 \pm 33$ & 5.2 \\
\hline $\begin{array}{l}\text { Proteinuria } \\
+ \text { - hemoglobinuria }\end{array}$ & $1+$ to $3+$ & & 19.1 \\
\hline Hemoglobinuria & $1+$ to $2+$ & & 4.5 \\
\hline
\end{tabular}

Table 2. Frequency of risk factors for chronic diseases in the examined population obtained by questionnaire, physical and laboratory examinations

\begin{tabular}{|c|c|c|}
\hline \multicolumn{2}{|l|}{ Risk factors } & $\begin{array}{c}\text { No }(\%) \text { of persons } \\
n=423\end{array}$ \\
\hline \multicolumn{2}{|l|}{ Gender, males } & $180(43 \%)$ \\
\hline \multicolumn{2}{|l|}{ Age $>60$ years } & $141(33 \%)$ \\
\hline \multirow{2}{*}{ BMI } & $25-29.9 \mathrm{~kg} / \mathrm{m}^{2}$ & $163(39 \%)$ \\
\hline & $>30 \mathrm{~kg} / \mathrm{m}^{2}$ & $137(32 \%)$ \\
\hline \multicolumn{2}{|l|}{ Diabetes } & $54(13 \%)$ \\
\hline \multicolumn{2}{|l|}{ Hypertension } & $179(42 \%)$ \\
\hline \multicolumn{2}{|l|}{ Hyperlipidemia } & $297(70 \%)$ \\
\hline \multicolumn{2}{|l|}{ Proteinuria } & $81(19 \%)$ \\
\hline \multirow{5}{*}{$\begin{array}{l}\text { Positive family history } \\
\text { for }\end{array}$} & hypertension & $178(42 \%)$ \\
\hline & CVD & $75(18 \%)$ \\
\hline & DM & $33(8 \%)$ \\
\hline & neoplasm & $17(4 \%)$ \\
\hline & CKD & $114(27 \%)$ \\
\hline \multicolumn{2}{|l|}{ Smokers } & $152(36 \%)$ \\
\hline \multicolumn{2}{|c|}{ Alcohol consumption - drinkers } & $198(47 \%)$ \\
\hline
\end{tabular}

$\mathrm{BMI}$ - body mass index; CVD - cardiovascular diseases; DM - diabetes mellitus; CKD - chronic kidney disease
(Table 4). Out of 63 patients with an ultrasound finding indicating liver steatosis, elevated serum transaminases were found in 22 patients and tumor was suspected in one of them. Seven patients with hepatomegaly and elevated transaminases, 13 patients with normal ultrasound finding but with elevated serum transaminases as well as 7 persons with tumor or suspected tumor were referred to the regional clinical center for further examination. Fourteen patients with normal ultrasound findings but slightly elevated serum transaminases as well as those with hepatomegaly without elevated serum transaminases, those with ultrasound signs for liver steatosis but without elevated serum transaminases will be followed and treated by their family doctors.

Five patients had previously diagnosed chronic pancreatitis and in one of them an increased serum $\alpha$-amylase level was found during screening.

Interviews revealed a high prevalence of gastrointestinal symptoms: 163 persons suffered from a sour sensation in the mouth, 41 had nausea, 13 vomiting and 26 melena. In 64 patients peptic gastric or duodenal ulcer had been previously diagnosed by radiographic or endoscopic evaluation. A diagnosis of gastritis was found in the medical documentation of 172 persons but it was confirmed by upper gastrointestinal radiography or endoscopy in only 47 patients. Nevertheless, many individuals used medicament therapy: 167 - antisecretory drugs, 30 - antacids and 21 - omeprazol, frequently in combination with antisecretory drugs. 
Table 3. Frequency of abdominal ultrasound abnormalities found in 423 adults from the communities of Velika Hoča and Orahovac

\begin{tabular}{|c|c|c|}
\hline Ultrasound findings & \multicolumn{2}{|c|}{ Number of persons } \\
\hline \multicolumn{3}{|l|}{ Liver } \\
\hline Steatosis & \multicolumn{2}{|c|}{63} \\
\hline Hepatomegaly & \multicolumn{2}{|c|}{19} \\
\hline Tumor & \multicolumn{2}{|c|}{2} \\
\hline Cyst & \multicolumn{2}{|c|}{3} \\
\hline Other focal lesion & \multicolumn{2}{|c|}{5} \\
\hline Calcifications & \multicolumn{2}{|c|}{5} \\
\hline \multicolumn{3}{|l|}{ Gallbladder } \\
\hline Gallstone & \multicolumn{2}{|c|}{31} \\
\hline Post-cholecystectomy status & \multicolumn{2}{|c|}{21} \\
\hline Kidney & Right & Left \\
\hline Length $<8.0 \mathrm{~cm}$ & 5 & 6 \\
\hline $8.0-9.9 \mathrm{~cm}$ & 33 & 18 \\
\hline $10.0-11.9 \mathrm{~cm}$ & 150 & 122 \\
\hline$>12 \mathrm{~cm}$ & 212 & 256 \\
\hline Cysts & 21 & 27 \\
\hline Polycystic kidney & 4 & 4 \\
\hline Hydronephrosis & 3 & 5 \\
\hline Chronic pyelonephritis & 2 & 6 \\
\hline Kidney stone & 9 & 3 \\
\hline Ren duplex & 2 & \\
\hline
\end{tabular}

Eradication omeprazole-based triple therapy was given to three patients with diagnosed Helicobacter pylori.

Analysis of laboratory and sonography examinations showed that 123 (28.8\%) subjects had at least one pathological finding indicating injury to their kidney. Among them 41 reported a history of kidney or urinary tract disease and medical documentation was available. Previous kidney disease was also known for 11 persons in whom no pathological finding was found in this survey (see Table 4). The remaining 82 patients with markers for kidney disease found here were not aware of their kidney disease and they were invited to a control check-up. Seventy-two persons responded to the invitation and kidney disease was not confirmed in 26 persons. In the remaining 46 persons laboratory and ultrasound examination showed different abnormalities, which enabled the diagnosis of particular kidney or urinary tract diseases to be established in 24 patients (see Table 4). In the remaining 22 persons diagnosis of kidney disease remained unclear. Individual values of the examined parameters for this group are presented in Table 5. Reduced kidney size was found in three of these individuals but without any abnormalities in kidney shape and the pyelocaliceal system. Seven persons had eGFR below $60 \mathrm{ml} / \mathrm{min} / 1.73 \mathrm{~m}^{2}, 8$ had low-grade proteinuria, but the majority of them had at least one tubular dysfunction marker. A positive family history for kidney disease was reported by 12 (55\%) subjects. All these 22 persons were advised to undergo further investigations in one of the university clinical centers in Serbia.
Table 4. Diseases and disorders detected in examined population by the use of questionnaire, physical, laboratory and ultrasound examination and available medical documentation

\begin{tabular}{|c|c|c|}
\hline & Diagnosis & $\begin{array}{c}\text { Number } \\
\text { of persons }\end{array}$ \\
\hline \multirow{4}{*}{ Heart diseases } & ischemic heart disease & 25 \\
\hline & hypertensive cardiomyopathy & 17 \\
\hline & cardiomyopathy - unknown cause & 5 \\
\hline & arrhythmia & 20 \\
\hline \multicolumn{2}{|c|}{ Chronic obstructive pulmonary disease } & 9 \\
\hline \multirow{7}{*}{ Liver diseases } & liver cirrhosis & 5 \\
\hline & chronic hepatitis $B / C$ & $4 / 1$ \\
\hline & chronic hepatitis & 3 \\
\hline & steatosis $+\uparrow$ transaminases ${ }^{a}$ & 22 \\
\hline & hepatomegaly $+\uparrow$ transaminases ${ }^{a}$ & 7 \\
\hline & 个transaminases ${ }^{a}$ & 13 \\
\hline & tumor and suspected tumor & 7 \\
\hline Pancreatic disease & chronic pancreatitis & 5 \\
\hline \multirow{3}{*}{$\begin{array}{l}\text { Gastrointestinal } \\
\text { disease/symptoms }\end{array}$} & peptic ulcerb & 64 \\
\hline & gastritis $^{b}$ & 47 \\
\hline & persons using antisecretory therapy & 167 \\
\hline \multirow{11}{*}{$\begin{array}{l}\text { Kidney and urinary } \\
\text { tract diseases }\end{array}$} & polycystic kidney disease & $2+2^{d}$ \\
\hline & diabetic nephropathy & $2+4$ \\
\hline & tbc & 2 \\
\hline & kidney stone & $9+3$ \\
\hline & chronic renal failurec & $10+2$ \\
\hline & ESRD (hemodialysis) ${ }^{c}$ & 4 \\
\hline & nephrectomy ${ }^{e}$ & 2 \\
\hline & pyelonephritis & $6+2$ \\
\hline & urinary bladder tumor & 3 \\
\hline & prostate hyperplasia & $8+6$ \\
\hline & urinary tract infection & $4+5$ \\
\hline
\end{tabular}

${ }^{a}$ serum transaminase level elevated by more than twice the upper normal limit bpeptic gastric/duodenal ulcer or gastritis previously diagnosed by radiographic or endoscopic evaluation

${ }^{c}$ chronic renal failure or end-stage renal disease (ESRD) of unknown etiology dnumber of kidney diseases diagnosed before present systematic survey + number of kidney diseases detected at this survey

enephrectomy due to kidney stone according to anamnesis, medical documentation not available

\section{DISCUSSION}

Velika Hoča is an old settlement in the valley of Metohija, very well known since the Roman and Byzantine period of time that all together with a little town of Orahovac, is located on the hills around 400 meters above sea-level but encircled by a high mountains. Because of its littoral climate, which spread over the valley of the Beli Drim River, this region is very well known by its wine-growing tradition. According to the UN documents (8), rural population of Velika Hoča as well as the semi urban popula- 
Table 5. Individual results for 22 patients in which kidney disease markers were detected in the survey and control check-up

\begin{tabular}{|c|c|c|c|c|c|c|c|c|c|}
\hline & Sex/age & $\begin{array}{c}\text { eGFR, } \mathrm{ml} / \\
\mathrm{min} / 1.73 \mathrm{~m}^{2}\end{array}$ & u-protein, g/g Cr & $\begin{array}{c}\alpha_{1}-M G, m g / \\
m m o l ~ C r\end{array}$ & NAG, U/I & $\mathrm{AP}, \mathrm{U} / \mathrm{mmol} \mathrm{Cr}$ & $\begin{array}{c}\text { Urinary } \\
\text { sediment }\end{array}$ & $\begin{array}{l}\text { Kidney } \\
\text { length, } \mathrm{cm}\end{array}$ & $\begin{array}{l}\text { Family } \\
\text { history }\end{array}$ \\
\hline 1 & $\mathrm{~F} / 71$ & 101 & 0.167 & n.d. & 1.5 & 0.66 & 0 & n.a. & 0 \\
\hline 2 & $F / 31$ & 134 & 0.156 & n.d. & 1.1 & 0.39 & 0 & 119 & $H D$ \\
\hline 3 & $\mathrm{M} / 72$ & 94 & 0.211 & 1.81 & 1.4 & 0.12 & 0 & 91.5 & 0 \\
\hline 4 & $\mathrm{M} / 47$ & 121 & 0.097 & 3.11 & 4.4 & n.a. & 0 & 121 & $H D$ \\
\hline 5 & $M / 46$ & 94 & 0.405 & n.d. & 0.5 & 0.02 & 0 & 119.5 & $H D$ \\
\hline 6 & $M / 21$ & 135 & 0.476 & n.d. & 2.15 & 0.27 & 0 & 119.5 & 0 \\
\hline 7 & $\mathrm{M} / 30$ & 94 & 0.047 & n.d. & 1.2 & 0.13 & 0 & 123 & $H D$ \\
\hline 8 & $M / 74$ & 76 & 0.057 & 1.66 & 0.9 & 0.00 & 0 & 121 & 0 \\
\hline 9 & $\mathrm{~F} / 71$ & 93 & 0.171 & 2.71 & 3.85 & 0.40 & 0 & 120 & CKD \\
\hline 10 & $M / 46$ & 94 & 0.405 & n.d. & 0.5 & 0.03 & 0 & 120 & HD \\
\hline 11 & $\mathrm{~F} / 77$ & 48 & 0.027 & 5.88 & 2.55 & 0.18 & $\mathrm{Er}$ & 87 & CKD \\
\hline 12 & $\mathrm{~F} / 70$ & 29 & 0.042 & 8.27 & 3.15 & 0.56 & 0 & 114 & 0 \\
\hline 13 & $\mathrm{M} / 55$ & 45 & 0.027 & 1.67 & 2.05 & 0.40 & 0 & 115.5 & 0 \\
\hline 14 & $F / 62$ & 46 & 0.037 & 1.76 & 0.5 & 0.16 & 0 & 94 & $\mathrm{HD}$ \\
\hline 15 & $F / 19$ & 106 & 0.006 & n.d. & 3.65 & 0.02 & $\mathrm{Er}$ & 107 & 0 \\
\hline 16 & $M / 85$ & 55 & 0.019 & 1.538 & 0.55 & 0.00 & 0 & 105 & HD \\
\hline 17 & $F / 69$ & 76 & 0.009 & n.d. & 5.75 & 0.42 & 0 & 109 & 0 \\
\hline 18 & $F / 55$ & 73 & 0.010 & n.d. & 1.3 & 0.26 & 0 & 119 & 0 \\
\hline 19 & $F / 56$ & 45 & 0.015 & n.d. & 0.5 & 0.00 & 0 & 114 & $H D$ \\
\hline 20 & $F / 65$ & 73 & 0.306 & 5.52 & n.a. & 1.27 & Le & 115 & 0 \\
\hline 21 & F34 & 54 & n.a. & n.a. & n.a. & n.a. & 0 & 111 & $H D$ \\
\hline 22 & $\mathrm{M} / 44$ & 83 & 0.037 & n.d. & 0.45 & 0.15 & 0 & 117 & $H D$ \\
\hline
\end{tabular}

$\alpha_{1}-M G=\alpha_{1}$-microglobulin; NAG = N-acetyl-ß-d-glucosaminidase; $A P=$ alkaline phosphatase; $n . a .=$ not available; $n$.d. = not detectable; Er = erytrocytes; $\mathrm{Le}=$ leucocytes; $\mathrm{HD}=$ family member on regular hemodialysis; $\mathrm{CKD}=$ chronic kidney disease

tion of Orahovac that remained after the exodus in 1999 could be defined as poor. Although this study was stimulated by the data on increased prevalence of chronic kidney disease in these communities, coming there we decided to undertake a systematic health survey of adult inhabitants using all available resources.

The main objective of the present study was to find out the prevalence of risk factors for chronic diseases in this enclave in Kosovo. The most frequent risk factor was hyperlipidemia and the prevalence of hypercholesterolemia was even higher than reported in several other studies (9-11). In addition to hyperlipidemia, three other modifiable risk factors for coronary heart disease - hypertension, obesity (BMI $>30 \mathrm{~kg} / \mathrm{m}^{2}$ ) and smoking were reported with similar frequency (32\% to $42 \%$ ) and diabetes was found in $13 \%$ of the examined persons. All these factors are not only risk factors for coronary heart disease but also for chronic kidney disease (12). Moreover, 27\% of the examined persons had a positive family history for chronic kidney disease, 33\% were above 60 years old and $47 \%$ were drinkers. All these data show that the examined population was burdened with many risk factors for both coronary and chronic kidney disease and also for chronic liver disease.

Although cardiovascular diseases were common in the examined population the number of patients with detected heart disease was similar to that for liver, gastrointestinal and kidney diseases and disorders. These results indicated a different disease burden in this Serbian enclave in Kosovo and Metohia from that described both in other parts of Serbia and in other developing countries. Namely, among ten conditions in terms of disability and mortality in developing countries as well as in Serbia without Kosovo, cardiovascular disease, cancer, mental health and injuries ranked consistently as the top conditions (13-15). Gastrointestinal diseases, liver and kidney diseases, did not appear among the major causes of death and disability, but these three groups of disease were detected with similar frequency as heart disease in the examined rural enclave of Velika Hoča and Orahovac.

In our survey diagnostic procedures for cancer detection were insufficient, mental health was not examined and no burden of injuries could be detected in such a cross sectional study. That might influence the order of the most prevalent diseases but cannot change the finding of a similar screening prevalence for heart, gastrointestinal, liver and kidney diseases in this population. That could be partly explained by the specific lifestyle in this rural community, where it is a custom consume red wine during meals as in Mediterranean countries. Although diet of examined population differed from Mediterranean diet, it was reported that such light-moderate drinking could be cardioprotective (16). In addition, the rural population presented here showed a lower prevalence of some cardiovascular risk factors compared to other parts of Serbia. In Serbia without Kosovo $60 \%$ of the adult population are smokers $(17,18)$, while in Velika Hoča and 
Orahovac 36\% of adult inhabitants are smokers. Lower prevalence of smokers in rural than in urban areas have already been reported in different geographic regions $(19,20)$. In addition, as farmers and winegrowers, people from the examined rural communities undertake physical work throughout almost the whole year. On the other hand, long-term alcohol use increases the risk of liver disease and peptic ulcers, but hypertension, hyperlipidemia often occur regardless of obesity $(16,21)$. Hypertension and hyperlipidemia have been found as the most frequent risk factors in the examined population.

One of the objectives of the present study was to find out the prevalence of kidney diseases. Based on their medical history and examinations the prevalence of kidney and urinary tract disease in the population of Velika Hoča and Orahovac was calculated to be $9.9 \%$, while the prevalence of kidney disease was $7.0 \%$. There are no exact data on kidney disease prevalence in Serbia. According to medical records for out-patients and in-patients for 1983 to 1992, kidney and urinary tract diseases represented $3.0-4.2 \%$ of all diseases (22). Several cross-sectional studies in Western Europe reported the prevalence of chronic kidney disease to be between $4.1 \%$ and $8.1 \%$ (23). Data on kidney and urinary tract disease prevalence in the examined enclave could hardly be compared with these data but suggest that these communities might be placed among those with a high prevalence of kidney disease. We paid special attention to the analysis of data in 22 patients with markers for kidney disease but without a definite diagnosis. Twelve of these patients had a positive family history for chronic kidney disease but of unknown diagnosis, although 10 of them were on regular hemodialysis. In addition to low-grade proteinuria different markers for tubular dysfunction were found in 14 of 21 patients by the available laboratory findings. That suggested that these patients might suffer from tubulointerstitial disease but places of their residence are not known as Balkan nephropathy foci. Although most patients with tubular disorders, reduced GFR and a positive family history were of older age and asymptomatic, features attributed to Balkan nephropathy (24), without a kidney biopsy diagnosis of their kidney disease can only be speculated on.

\section{Acknowledgement}

This work was supported by the Ministry of Science of Serbia, contract No. 145043.

\section{REFERENCES}

1. Yach D, Hawkes C, Gould CL, Hofman KJ. The global burden of chronic diseases: overcoming impediments to prevention and control. JAMA. 2004 Jun 2;291(21):2616-22.

2. National Kidney Foundation. K/DOQI clinical practice guidelines for chronic kidney disease: evaluation classification, and stratification. Am J Kidney Dis. 2002 Feb;39(2 Suppl 1):S1-266.

3. Beaglehole R, Ebrahim S, Reddy S, Voûte J, Leeder S; Chronic Disease Action Group. Prevention of chronic diseases: a call to action. Lancet. 2007 Dec 22;370(9605):2152-7.
4. Šubarić Gorgieva G, Krčmarević J, Ristić S, Hristić G. The prevalence of hypertension in a cohort of patients from a region afflicted by Balkan nephropathy: its relationship to renal function and obesity. XXIVth Arterial Hypertension Days. Arch mal coeur vaiss. 2004;97:57-8. (In French.)

5. Filijovic L, et al. Inhabitants of Velika Hoča: health problems during the year 2002. Praxis Med. 2003;31 Suppl 1-2:239-40.

6. Grković D. Torment of Serbian population in Orahovac and condition of patients in period 1999-2002. Praxis Med. 2003;31 Suppl 1-2:235-8.

7. Levey AS, Bosch JP, Lewis JB, Greene T, Rogers N, Roth D. A more accurate method to estimate glomerular filtration rate from serum creatinine: a new prediction equation. Modification of Diet in Renal Disease Study Group. Ann Intern Med. 1999 Mar 16;130(6):461-70.

8. United Nations. Poverty and the international covenant on economic, social and cultural rights: 10/05/2001. E/C.12/2001/10. Geneva: Office of the UN High Commissioner for Human Rights; 2001.

9. Tyrovolas S, Lionis C, Zeimbekis A, Bountziouka V, Micheli M, Katsarou A, et al. Increased body mass and depressive symptomatology are associated with hypercholesterolemia, among elderly individuals; results from the MEDIS study. Lipids Health Dis. 2009 Mar 30;8:10.

10. Costa J, Borges M, Oliveira E, Gouveia M, Carneiro AV. Incidence and prevalence of hypercholesterolemia in Portugal: a systematic review. Part I. Rev Port Cardiol. 2003 Apr;22(4):569-77.

11. Tezcan S, Altintaş H, Sönmez R, Akinci A, Doğan B, Cakir B, et al. Cardiovascular risk factor levels in a lower middle-class community in Ankara, Turkey. Trop Med Int Health. 2003 Jul;8(7):660-7.

12. Fox CS, Larson MG, Leip EP, Culleton B, Wilson PW, Levy D. Predictors of new-onset kidney disease in a community-based population. JAMA. 2004 Feb 18;291(7):844-50.

13. Jankovic S, Vlajinac H, Bjegovic V, Marinkovic J, Sipetic-Grujicic S, Markovic-Denic L, et al. The burden of disease and injury in Serbia. Eur J Public Health. 2007 Feb;17(1):80-5.

14. World Health Organization. Preventing chronic diseases: a vital investment. Geneva: WHO; 2005.

15. Anderson GF, Chu E. Expanding priorities - confronting chronic disease in countries with low income. N Engl J Med. 2007 Jan 18;356(3):209-11.

16. Agarwal DP. Cardioprotective effects of light-moderate consumption of alcohol: a review of putative mechanisms. Alcohol Alcohol. 2002 SepOct;37(5):409-15.

17. Sokolova-Djokic L, Zizic-Borjanovic S, Igic R. Cigarette smoking in Serbia. Impact of the 78-day NATO bombing campaign. J BUON. 2008 Apr-Jun;13(2):285-9.

18. Tobacco control database [Internet]. Geneva: WHO Regional Office for Europe [cited 2009 Aug 28]. Available from: http://www.euro.who.int/.

19. Kwaśniewska M, Kaleta D, Dziankowska-Zaborszczyk E, Drygas W. Healthy behaviours, lifestyle patterns and sociodemographic determinants of the metabolic syndrome. Cent Eur J Public Health 2009 Mar;17(1):149

20. Chapman A, Bunker S, Dunbar J, Philpot B, McNamara K, Baird A, et al. Rural smokers - a prevention opportunity. Aust Fam Physician. 2009 May;38(5):352-6.

21. Yokayama H, Hirose H, Saito I. Two types of unsafe drinker judged to have metabolic syndrome: typical metabolic syndrome or alcohol-related syndrome? Med Sci Monit. 2009 Jun;15(6):PH57-64.

22. Janković S, Djordjević V, Djukanović L. Descriptive epidemiological characteristics of nephrourological diseases in Serbia. Mac Med Review. 1997;Suppl 35:18-9.

23. Zhang QL, Rothenbacher D. Prevalence of chronic kidney disease in population-based studies: systematic review. BMC Public Health. 2008 Apr 11;8:117.

24. Stefanović V, Radovanović Z. Balkan endemic nephropathy and associated urothelial cancer. Nat Clin Pract Urol. 2008 Feb;5(2):105-12.

Received August 28, 2009

Accepted in revised form January 8, 2010 